\title{
PENERAPAN PRINSIP ETIK KEPERAWATAN DALAM TAHAPAN \\ PENGAMBILAN KEPUTUSAN
}

\author{
Kiki Dwi Febriyanti
}

kiifeb83@gmail.com

\section{LATAR BELAKANG}

Salah satu indikator kunci keberhasilan suatu rumah sakit dalam mamberikan pelayanan kesehatan ditentukan oleh kinerja tenaga keperawatan dalam memberikan pelayanan asuha keperawatan. Profesi perawat di Indonesia memiliki proporsi relative besar yaitu $40 \%$ dari jumlah tenaga kesehatan di Indonesia, sehingga baik buruk kinerja perawat menjadi salah satu indikator utama mutu asuhan keperawatan di rumah sakit atau instansi kesehatan yang lain. (Saragih, 2011, p. 1). dikutip dari Berger \& Williams(1999), etika keperawatan adalah nilai-nilai dan prinsip-prinsip yang diyakini oleh profesi keperawatan dalam melaksanakan tugasnya yang berhubungan dengan pasien, masyarakat, teman sejawat, maupun dengan organisasi profesi. , dan juga dalam pengaturan praktik keperawatan itu sendiri. Prinsip-prinsip etika ini oleh profesi keperawatan secara formal dituangkan dalam suatu kode etik yang merupakan komitmen profesi keperawatan akan tanggung jawab dan kepercayaan yang diberikan oleh masyarakat (Pangaribuan, 2016).

Pelaksanaan prinsip etik dapat mencegah terjadinya bahaya fisik dan emosional bagi pasien dalam asuhan keperawatan. Pelaksanaan prinsip etik merupakan salah satu dari 12 kompetensi dasar yang harus dimiliki oleh seorang perawat. Tujuan penulisan ini adalah untuk penerapan prinsip etik keperawatan dalam tahapan pengambilan keputusan. Kinerja perawat menerapkan prinsip etik penting untuk dilakukan mengingat perawat yang dalam melakukan asuhan keperawatan berperilaku tidak etik dapat menimbulkan kerugian bagi pasien sebagai penerima asuhan keperawatan yaitu dapat mengalami injury atau bahaya fisik seperti nyeri, kecacatan atau kematian, serta bahaya emosional seperti perasaan tidak berdaya atau terisolasi (CNA, 2004). Oleh karena itu, perawat dalam memberikan asuhan keperawatan wajib berpedoman terhadap prinsip-prinsip etik keperawatan 
yaitu autonomy (penentuan diri), non maleficience (tidak merugikan), beneficience (melakukan hal baik), justice (keadilan), veracity (kejujuran) dan fidelity (menepati janji). (kozier, 2015, p.94).

\section{METODE}

metode yang digunakan dalam penulisan ini adalah metode kajian bebas dimana metode ini berwilayah lebih sempit dengan tingkat variasi yang rendah, namun dari penulisan ini dapat berkembang menjadi lebih luas. Metode kajian bebas ini merupakan metode yang dilakukan untuk melakukan penulisan yang dikumpulkan dari beberapa sumber seperti buku teks, buku referensi jurnal dan e-book, dan juga dibandingkan dengan jurnal yang berhubungan dengan "pentingnya berpikir kritis dalam menyelesaikan tahapan proses keperawatan". Sehingga pembaca dapat mengerti informasi yang sudah ditulis dan dapat memahami pentingnya berpingnya berpikir kritis dalam menyelesaikan tahapan proses keperawatan.

\section{HASIL}

Perawat adalah tenaga kerja yang dituntut untuk memiliki tingkat kepedulian yang tinggi kepada pasien dalam memberikan pelayanan kesehatan. Perawat dituntut untuk memberikan pelayanan dengan baik sesuai dengan prinsip etik keperawatan seperti autonomy (kebebasan), nonmaleficience (Tidak Merugikan), beneficience (Berbuat Baik), veracity (Kejujuran), justice (Keadilan), fidelity (Kesetiaan), confidentiality (Kerahasiaan) dan accountability (Bertanggung jawab) supaya pasien dapat memperoleh hak dan kewajibannya secara penuh sebagai pasien.

Dikutip dari Berger \& Williams(1999), etika keperawatan adalah nilai-nilai dan prinsip-prinsip yang diyakini oleh profesi keperawatan dalam melaksanakan tugasnya yang berhubungan dengan pasien, masyarakat, teman sejawat, maupun dengan organisasi profesi. , dan juga dalam pengaturan praktik keperawatan itu sendiri. Prinsip-prinsip etika ini oleh profesi keperawatan secara formal dituangkan dalam suatu kode etik yang merupakan komitmen profesi keperawatan akan tanggung jawab dan kepercayaan yang diberikan oleh masyarakat (Pangaribuan, 2016).

Sri lestari (2004) melaporkan bahwa persepsi perawat terhadap prinsip-prinsip etika meliputi, agama mengajarkan bebuat baik, tidak membedakan, mendapatkan persetujuan melakukan tindakan, pasien atau keluarga pasien berhak menolak tindakan, mendahulukan tindakan sesuai dengan prioritas masalah, melakukan tindakan untuk kebakan, menghindari hal- 
hal yang membahayakan pasien, menghargai pasien dan keluarga yang menggunakan cara-cara tradsional.

\section{PEMBAHASAN}

Rumah sakit adalah institusi pelayanan kesehatan yang menyelenggarakan pelayanan kesehatan perorangan secara paripurna, yang menyediakan pelayanan rawat inap, rawat jalan dan rawat darurat (UU RS no 44 tahun 2009). Seiring dengan perkembangan zaman, maka rumah sakit yang dulunya mempunyai misi charity (sosial) sekarang harus dapat menyeimbangkan antara misi bisnis yang berorientasi profit serta misi pengembangan ilmu pengetahuan dan teknologi tanpa melupakan misi sosialnya. Hal ini sesuai dengan ketentuan Departemen Kesehatan yang mengharuskan rumah sakit untuk mengalokasikan $20-30 \%$ pendapatan rumah sakit bagi masyarakat kurang mampu (Depkes RI Dirjen Yanmed, 2005).

Perawat memiliki peran yang cukup tinggi dalam memberikan pelayanan asuhan keperawatan, baik di rumah sakit, maupun di masyarakat. Keperawatan adalah kegiatan pemberian asuhan keperawatan, baik kepada individu, keluarga, kelompok, atau masyarakat, baik dalam keadaan sakit maupun sehat. Perawat yaitu seseorang yang telah dinyatakan lulus pendidikan tinggi keperawatan, baik di dalam maupun di luar negeri yang telah diakui oleh pemerintah sesuai dengan ketentuan dan Peraturan Perundang-undangan (UU No 38 tahun 2014). Perawat dalam menjalankan praktik asuhan keperawatan harus sesuai dengan standar operasional prosedur, standar pelayanan profesi, oleh karena itu perawat dalam menjalankan tindakan pelayanan asuhan keperawatan harus berpedoman pada prinsip etika keperawatan agar tidak terjadi kesalahan maupun kelalaian yang dapat merugikan pasien maupun perawat serta Rumah Sakit (Riko, 2015).

Prinsip etik keperawatan yang harus diterapkan oleh perawat dalam menjalankan praktik asuhan keperawatan ada 8 prinsip etik, antara lain:

a) Prinsip autonomy (kebebasan) yaitu prinsip menghormati otonomi klien, dimana klien dan keluarga bebas dan berhak untuk memilih dan memutuskan apa yang akan dilakukan perawat terhadapnya.

b) Prinsip beneficience (berbuat baik) yaitu setiap tindakan yang dilakukan oleh perawat harus memiliki manfaat kepada klien maupun keluarga klien.

c) Prinsip nonmaleficience (tidak merugikan) yaitu tindakan perawat harus sesuai prosedur agar tidak terjadi 
kesalahan maupun kelalaian yang dapat merugikan klien maupun keluarga.

d) Prinsip justice (keadilan) yaitu tindakan perawat dalam memberikan pelayanan dilarang membeda-bedakan antara klien satu dengan klien lainnya.

e) Prinsip veracity (kejujuran) yaitu perawat diwajibkan berkata jujur dan jelas terhadap apa yang akan dilakukannya kepada klien maupun keluarga klien.

f) Prinsip fidelity (menepati janji) yaitu perawat dalam memberikan pelayanan harus setia kepada klien serta memiliki komitmen dalam memberikan pelayanan dengan baik.

g) Prinsip accountability (bertanggungjawab) yaitu perawat harus bertanggungjawab mengenai tindakan yang dilakukan terhadap klien maupun keluarga.

h) Prinsip confidentiality (kerahasiaan) yaitu perawat harus menjaga rahasia setiap klien, baik pada saat klien masih hidup maupun sudah meninggal (Utami, 2016).

Contoh kasus pengaplikasian pengambiln keputusan dengan prinsip etik dalam keperawatan:

Seorang laki-laki usia 65 tahun menderita kanker kolon terminal dengan metastase yang telah resisten terhadap tindakan kemoterapi dan radiasi dibawa ke IGD karena jatuh dari kamar mandi dan menyebabkan robekan di kepala. laki-laki tersebut mengalami nyeri abdomen dan tulang dan kepala yang hebat dimana sudah tidak dapat lagi diatasi dengan pemberian dosis morphin intravena. Hal itu ditunjukkan dengan adanya rintihan ketika istirahat dan nyeri bertambah hebat saat laki-laki itu mengubah posisinya. Walapun klien tampak bisa tidur namun ia sering meminta diberikan obat analgesik. Kondisi klien semakin melemah dan mengalami sesak yang tersengal-sengal sehingga mutlak membutuhkan bantuan oksigen dan berdasar diagnosa dokter, klien maksimal hanya dapat bertahan beberapa hari saja.

Melihat penderitaan pasien yang terlihat kesakitan dan mendengar informasi dari dokter, keluarga memutuskan untuk mempercepat proses kematian pasien melalui euthanasia pasif dengan pelepasan alat-alat kedokteran yaitu oksigen dan obat obatan lain dan dengan keinginan agar dosis analgesik ditambah. Dr spesilalist onkologi yang ditelp pada saat itu memberikan advist dosis morfin yang rendah dan tidak bersedia menaikan dosis yang ada karena sudah maksimal dan dapat bertentangan dengan UU yang ada. Apa yang seharusnya dilakukan oleh anda selaku perawat yang berdinas di IGD saat 
itu menghadapi desakan keluarga yang terus dilakukan?

Pemecahan dilemma etis menurut kozier (2004)

1. Mengembangkan data dasar

a) Orang yang terlibat:

- Keluarga

- Pasien

- Perawat

- Dokter

b) Tindakan yang diusulkan : euthanasia pasif kepada pasien

c) Maksud dari tindakan : keluarga tidak tega melihat pasien yang kesakitan

d) Konsekuensi tindakan : hilangnya nyawa pasien secara perlahan

2. Identifikasi konflik

Tidak disetujuinya euthanasia dengan cara menambah dosis obat karena akan melanggar UU :

- Pasal 365 (3) KUHP yang juga mengancam terhadap "penganiayaan yang dilakukan dengan memberikan bahan yang berbahaya bagi nyawa dan kesehatan untuk dimakan dan diminum". Selain itu patut juga diperhatikan adanya ketentuan dalam Bab XV KUHP khususnya pasal 304 dan pasal 306 (2).

- Pasal 306 (2) KUHP dinyatakan "jika mengakibatan kematian, perbuatan tersebut dikenakan pidana penjara maksimal Sembilan tahun".

- Para dokter di Indonesia dilarang melakukan euthanasia. Di dalam kode etik itu tersirat suatu pengertian, bahwa seorang dokter harus mengerahkan segala kepandaiannya dan kemampuannya untuk meringankan penderitaan dan memelihara hidup manusia (pasien), tetapi tidak untuk mengakhirinya.

3. Alternative tindakan :

Tetap dilakukan tindakan pengobatan sebagaimana mestinya tanpa harus melanggar hukum, karena euthanasia di Indonesia tidak diperbolehkan.

4. Menentukan siapa pengambil keputusan yang tepat :

Pengambil keputusan yang tepat untuk kasus ini adalah keluarga dari pasien, karena keluarga adalah yang paling berhak atas diri pasien.

5. Kewajiban perawat :

- Memberikan pengertian kepada keluarga pasien bahwa permintaannya ( euthanasia) adalah perbuatan yang menggelar hukum dan di Negara Indonesia melarang tindakan tersebut.

- Perawat harus memberikan semangat kepada pasien agar tetap tabah menjalani penyakitnya walau 
hasil akhirnya nanti ia tetap meninggal dunia.

6. Membuat keputusan:

Keputusan yang akan dilakukan adalah melaksanakan pengobatan/tetapi sebagaimana mestinya tanpa harus mempercepat kematian pasien dengan berbagai alasan, karena akan melanggar hukum yang telah berlaku di Indonesia.

Perawat yang memiliki pengetahuan tentang prinsip etik harus menerapkannya dalam pemberian asuhan keperawatan pada pasien agar dapat meningkatkan kepuasan dan kepercayaan antar perawat, klien dan petugas kesehatan lain. Hubungan saling percaya dapat meningkatkan keyakinan pasien akan pelayanan kesehatan yang aman dan berkualitas yang didapatkan dari perawat (Malau, 2008 dalam Indrastuti, 2010, p.4).

Dalam menerapkan prinsip etik, untuk menentukan pengambilan keputusan bagi seorang perawat ketika menangani seorang pasien yang berada dalam kondisi kritis dengan rasa nyeri yang sudah tidak bisa lagi ditahan, lalu pihak keluarga meminta agar pasien tersebut dilakukan pencabutan alat-alat bantu rumah sakit atau dengan kata lain dilakukan euthanasia. Sungguh saat itu adalah dilema etik yang dirasakan perawat, apakah mengikuti anjuran dokter untuk memberikan obat pereda nyeri atau mengikuti permintaan pihak keluarga. Merupakan sebuah dilema etik yang harus dilewati oleh seorang perawat ketika bertemu dengan pasien seperti itu.

\section{PENUTUP}

\section{Kesimpulan}

Pelaksanaan prinsip etik dapat mencegah terjadinya bahaya fisik dan emosional bagi pasien dalam asuhan keperawatan. Kinerja perawat menerapkan prinsip etik penting untuk dilakukan mengingat perawat yang dalam melakukan asuhan keperawatan berperilaku tidak etik dapat menimbulkan kerugian bagi pasien sebagai penerima asuhan keperawatan yaitu dapat mengalami injury atau bahaya fisik seperti nyeri, kecacatan atau kematian, serta bahaya emosional seperti perasaan tidak berdaya atau terisolasi (CNA, 2004). Oleh karena itu, perawat dalam menetapkan sebuah keputusan untuk memberikan asuhan keperawatan wajib berpedoman terhadap prinsip-prinsip etik keperawatan yaitu autonomy (penentuan diri), non maleficience (tidak merugikan), beneficience (melakukan hal baik), justice (keadilan), veracity (kejujuran) dan fidelity (menepati janji).

\section{Saran}

sebagai seorang perawat yang professional, apapun tindakan yang akan 
dilakukan sebaiknya berpikir dengan cepat dan tanggap, terutama dalam menentukan sebuah keputusan asuhan keperawatan. Semoga apa yang sudah diberikan melalui penulisan ini dapat diterima dan dikembangkan lagi menjadi tulisan yang lebih efisien dan bermanfaat.

\section{DAFTAR PUSTAKA}

Amelia, N. (2013). Prinsip Etika Keperawatan. Yogyakarta: D- Medika. Buchbinder, S. B., \& Shank, N. H.(2014). Manajemen Pelayanankesehatan [Palupi Widyastuti \& Estu Tiat, Alih Bahasa]. Jakarta: Egc.

Fadhillah, N., \& Jannah, N. (2017). Pelaksanaan Prinsip Etik Keperawatan Dalam Asuhan Keperawatan Pada Perawat Pelaksana. Jurnal Ilmiah Mahasiswa Fakultas Keperawatan, 2(3).

Feriadi, A., Purwanti, E., \& Novyriana, E. (2020). Gambaran Tingkat Penerapan Prinsip Etik Keperawatan Di Ruang Rawat Inap Kelas Iii Rumah Sakit Pku Muhammadiyah Gombong. Jurnal Ilmiah Kesehatan Keperawatan, 16(1).

Firmansyah, I. R. F. A. N. Gambaran pengetahuan dan Sikap perawat tentang kode etik keperawatan di Rumah Sakit Daerah Kalisat Kabupaten Jember" (Doctoral dissertation, Fakultas Keperawatan).

Nasrullah, D. (2014). Etika Dan Hukum Keperawatan Untuk Mahasiswa Dan Praktisi Keperawatan. Jakarta: Tim.

Notoatmodjo, S. (2012). Etika Dan Hukum Kesehatan. Jakarta: Rineka Cipta.

Padang, A. S. Analisis Faktor-Faktor Yang Mempengaruhi Kepala Ruangan Rawat Inap Rumah Sakit Terhadap Pengambilan Keputusan.Osf.Io. Rahayu, C. D., \& Mulyani, S. (2020). Pengambilan Keputusan Klinis Perawat. Jurnal Ilmiah Kesehatan, 10(1), 1-11

Simamora, R. H. (2005). Hubungan Persepsi Perawat Pelaksana Terhadap Penerapan Fungsi Pengorganisasian Yang Dilakukan Oleh Kepala Ruangan Dengan Kinerjanya Diruang Rawat Inap Rsud Koja Jakarta Utara (Doctoral Dissertation, Tesis Fik Ui, Tidak Dipublikasikan).

Simamora, R. H. (2019). Menjadiperawat Yang: Cih'huy. Surakarta: Kekata Publisher. 
